\title{
The Concept of Production, Distribution, and Consumption in Islamic Economics
}

Rizky Maidan Ilmy, Iwan Setiawan

UIN Sunan Gunung Djati Bandung

Email: rizkyilmy66@gmail.com, iwansetiawan@uinsgd.ac.id

\begin{abstract}
During the last two decades, two economic ideologies that experienced world development, namely socialism, and capitalism, competed to prove themselves as the most rightful and the most potential in solving economic problems people face. However, both of them were judged to serve solutions in solving people's main classic economic problem. Islamic Economy was introduced as the alternative in solving the problems. One of the ideas from Islamic Economy ideologies is the concept of production, distribution, and consumption. The research methodology, which was used in the research was thedescriptive-qualitative method. The data collection was conducted by combining theories from different references. The research aims to acknowledge how the concept of production, distribution, and consumption in the Islamic Economy works. The research findings include: 1) the production concept in Islamic Economy should be based on three central fundamental aspects, namely the aspect of belief, knowledge, and deed; 2) the production concept in Islamic Economy should be based on the basic principle of Islamic Economy namely individual freedom, social insurance, prohibition in accumulating wealth, and fair wealth distribution; 3) the concept of consumption in Islamic Economy to only fulfill daily needs, not the wants.
\end{abstract}

Keyword: Production, Distribution, Consumption, and Islamic Economy

\section{INTRODUCTION}

During the last two decades, two economic ideologies, namely socialism, and capitalism, were developed throughout the world as they competed to serve their influence towards countries. They both competed against each other to prove themselves as the rightest and the most efficient in solving faced economic problems. Supporters from each ideology were competing to show arguments and presenting the supporting concepts to show their ideology was the toughest and would survive in an extended period. However, as time passes by, the failure indication of these two ideologies was getting more transparent. Both of them were labeled as a failure to introduce solutions in solving the main problem of the human economy.

Present time shows the visible reality, which majorly depicts injustice and inequality in the distribution of income and wealth in developed countries and developing countries who use capitalist economic systems as their ideologies or economic concepts, thus creating poverty everywhere. Today's production activities, as an example, are more often affixed with mechanisms, models, and production strategies that override values, ethics, and moral judgment, as well as the influence of the holidays moment, which leads many producers to do ihtikar or hoarding. As a result, production goods will be scarce. In addition, producers often carry out production activities such as cheating on scales, covering production flaws, etc.

Furthermore, Ermawati Usman, in her research entitled Producer Behavior in Islamic Business Ethics, found that there were other forms of cheating: producers who produce goods using labels or famous brands. Moreover, the traditional market sellers are also rife with using tools such as lights, which will tailor the product's color to make it look fresher to achieve maximum profit (Usman, 2007).

Besides Ermawati, Azhari Akmal Tarigan revealed several forms of unhealthy market competition, predatory pricing. This behavior is dominated by large companies that even become market leaders who try to sell their products below the production price with the aim of 
Reducing or even removing competitors in the market. This predatory pricing becomes an irony. Therefore, in addition to consumers harming, it will also lead to an unhealthy market, resulting in a disadvantage for the customer. At the same time, the classical economic approach states that the three main economic problems which become a single entity, namely production, distribution, and consumption, need to be solved and solutions are sought so that a situation where all the goods and services needed can be available and sufficient to create prosperity in the community.

Islam as a universal belief with a systematical concept of economics presents an alternative expected to solve these problems. The statement is not a simple idea but has the support of the world's leading economist Anthony Gidden, as quoted by Agustianto in his book The Third Way, stating that the world should seek a third path from the struggle of the enormous world system, capitalism, and socialism. It is not excessive if the third awaited way is the Islamic Economy. Responding to the reality of the economic problems that occur, the focus of the discussion in this article will discuss how the concepts of production, distribution, and consumption in the Islamic Economy works.

\section{LITERATURE REVIEW}

\section{Theoretical Foundation}

\section{a. Production}

Production defines as the center of economic activity. There will never be consumption, distribution, or trade-in goods and services without starting the production process regarding the economy. Therefore, production is an effort of a person or group to release themselves from fidelity. Production means physically creating something that has not existed yet. What can be done to make goods helpful from various production activities is that no one can create natural objects (Turmudi, 2017).

Generally, production means a process for producing goods and services or increasing the value of an object. This is in line with the opinion of Aslam Haneef, who sees production as a utility creation. However, conventional economy production activities sometimes forget where the product will be distributed. As long as efficiency is achieved and get maximum profits, it will continue to be finished. This is not following the Islamic economic concept that the goods and services produced must improve economic welfare (Haneef, 2010).

b. Distribution

Distribution describes the movement of goods from manufacturing companies to the market and finally at the hand of consumers. Distribution has a close relationship with the level of welfare in a society. Distribution theory in capitalist economics gives freedom to own and strive for all individual societies. Every society could get wealth as possible according to the factors of production, but it does not pay attention to the fair and even distribution for all individuals. In the point of Islamic Economics' view, the concept of a capitalist economic system labels as dzalim as it results in wealth accumulation in a specific group (Rahmawaty, 2013).

\section{c. Consumption}

Consumption is the essential goal of the product, as production is needed as long as there is still consumption. Consumption understands as the final part of the production. It makes production can stop, but consumption cannot stop. Consumption depends on income. If a person's income increases, consumption will also increase as humans always desire to consume (propensity to consume) (Rasyid, 1998).

According to Samuelson, consumption is an activity, which consumes the utility (value of use) of goods and services. Consumer of the goods according to their needs are divided into three, namely primary needs, secondary needs, and tertiary needs (Hans, 1993).

Therefore, consumption is a beneficial spend that is useful in physically achieving the needs of life or their household, which aims to satisfy human needs. This means that the purpose of consumption is find the highest satisfaction with the determination of goods or services to be consumed based on 
Satisfaction criteria regardless of whether the goods or services bring benefits so that finally the consumption limit is only budgetary capacity. As long as you still have a budget to buy goods or services, it will continue to be finished. Thus, no one can prevent consuming desired goods as long as the community has income. This attitude clearly will negate consideration of the interests of others or consideration of other aspects such as halal and appetence. In this concept, satisfaction results from the utility, so satisfaction and utility are considered the same in a capitalist economic system (P3EI, 1989).

\section{PREVIOUS RESEARCH}

Widya Sari (2014) conducted research that focused on the concept of Islamic consumption based on halal and sound principles, the principle of nothingness follows lust, and the principle of gratitude. The concept of production and distribution in Islam must prioritize the value of freedom in interaction and participation based on religion and the value of justice in relationships based on two joints: freedom and prosperity. Furthermore, in here research, Fahrudin Sukarno (2010) states that the conceptual framework of the Islamic production concept is emerging the morality basic to implement production activities. This basic morality will affect economic growth, distributive justice, environmental conservation program, and corporate social responsibility. Arif Pujiono (2006) states that consumption in Islamic economics has been arranged in the frame of sharia to guide a Muslim to not fall prey to what is consumed, and what he consumes becomes a blessing. In addition, Anita Rahmawaty (2013) states that the distribution of Islamic economics in distributive justice and the mechanism of distribution in Islam become a solution to justice and public welfare.

\section{RESEARCH METHODOLOGY}

The research methodology used was descriptive qualitative. Thus, the data collection was conducted by searching for any references related to the current reviewed topic. Afterward, related found theories were combined.

\section{FINDING AND DISCUSSION}

\section{1) Finding}

d. Production

Production is the center of economic activity. There will never be consumption, distribution, or trade-in goods and services in economic life without starting the production process. Therefore, production is an effort of a person or group to release themselves from fidelity. Production does not mean physically creating something that has not existed yet only, but what can be done is to make goods useful from various kinds of production activities because no one can create genuine new objects (Turmudi, 2017).

Generally, production is a process for producing goods and services or increasing the value of an object. This is in line with the opinion of Aslam Haneef, who sees production as a utility creation. However, conventional economy production activities sometimes forget where the product will be distributed. As long as efficiency is achieved and get maximum profits, it will continue to be finished. This is not following the Islamic economic concept that the goods and services produced must improve economic welfare (Haneef, 2010).

e. Distribution

Distribution describes the movement of goods from manufacturing companies to the market and finally at the hand of consumers. Distribution has a close relationship with the level of welfare of society. Distribution theory in capitalist economics gives freedom to own and strive for all individual societies so that every society could get as much wealth as possible according to the factors of production but ignores whether the distribution is felt fairly and evenly by all individuals or only a handful of people only. In the point of Islamic Economics' view, the concept of a capitalist economic system labels as dzalim as it results in wealth accumulation in a particular group. 
(Rahmawaty, 2013).

f. Consumption

Consumption is the essential goal of the product, as production is needed as long as there is still consumption. Consumption is the final part of the production so that production can stop, but consumption cannot stop. Consumption depends on income. If a person's income increases, consumption will also increase. Because humans always have the desire to consume (propensity to consume) (Rasyid, 1998). According to Samuelson, consumption is an activity, which consumes the utility (value of use) of goods and services. Consumer goods, according to their needs, are divided into three, namely primary

needs, secondary needs, and tertiary needs (Hans, 1993).

Therefore, consumption is a beneficial spend that is useful in achieving the needs of life physically or household, which aims to satisfy human needs. This means that consumption aims to find the highest satisfaction with the determination of goods or services to be consumed based on satisfaction criteria regardless of whether the goods or services bring benefits so that finally, the consumption limit is only budgetary capacity. As long as you still have a budget to buy goods or services, it will continue to be finished. Thus, no one can prevent consuming desired goods as long as the community has income. This attitude clearly will negate consideration of the interests of others or consideration of other aspects such as halal and appetence. In this concept, satisfaction results from utility, so satisfaction and utility are considered the same in a capitalist economic system (P3EI, 1989).

\section{Discussion}

a. Islamic Production

Production in Islamic Economic, which is included in Fiqh of Umar bin Khattab could be previewed from three kind aspects (Al-Haritsi, 2003) :

The first aspect is belief. Islam teaches that every activity would always be related to worship (Qur'an of surah Adz-Dzariyat verse 56) so that economic activities are included in the area of worship (Yunia \& Kadir, 2014). Thus, the element of production in Islam must be based on the concept of istikhlaf, where humans must be responsible for prospering the world and also investing and developing assets mandated by Allah to cover human needs. This is in line with the duty of humans as caliphs on earth (Qur'an of surah Al-Baqarah verse 30). One of the tasks is to manage resources provided by Allah efficiently and optimally without causing damage on earth so that welfare and justice can be upheld and can obtain utility or practical use of resources following Islamic teachings. Production activities are created because of the need. Therefore, the concept of production in Islam must consider aspects of needs, not desires. According to al-Syathibi, the formulation of human needs in Islam consists of three types, namely dharuriyat (primary), hajiyat (secondary), and tahsiniyat (tertiary) (Yunia \& Kadir, 2014). Producing the dharuriyat sector or the most essential needs must take precedence over the hajiyat and tahsiniyat. This must be done. Thus people can live a decent life because if the primary needs are not achieved, human life will be threatened, and this is not following the goals of maqasid alshari'ah, namely as a manifestation of benefit among humans.

The second aspect is knowledge, and the knowledge aspect teaches MuslimsMuslims must learn sharia laws are related to economic activities to understand the good and evil. Studying sharia law related to economic activity is mandatory. It is based on the provisions contained in the commandments of Islamic teachings (Ja'far, 2012). The order instructs to conduct in totality in all activities, including in the economic field (Qur'an of surah Al-Baqarah verse 208). In terms of the production of goods, according to Imam al-Ghazali, the production of basic needs is seen explicitly as a social obligation (fardhu al-kifayah). If there are already producing and the amount is sufficient, the individual loses the obligation to produce items. On the contrary, if no one produces goods and results could not fulfill the needs, they will be judged in the hereafter. Thus, the state must be responsible and guarantee that the goods produced are sufficient (Karim, 2011).

The third aspect is deed, which applies the aspects of belief and knowledge that impact the quality of sound production and have implications for good distribution. The attitude that must be carried out in Islamic economics is to avoid negative externalities, make natural resources efficient, continuously innovate, prioritize dharuriyat, and always aim for benefit (individuals, families, communities, living things, and the earth) (Yunia \& Kadir, 2014). 


\section{b. Islamic Distribution}

One of the human economic activities besides production and consumption is distribution (Sudarsono, 2002). The teachings of Islam require people always to try to live a balanced life, namely by paying attention to the welfare of life in the world and salvation in the hereafter (Rahmawaty, 2013). One of the main principles in the Islamic economy is distributive justice. Distribution activities in the Islamic economic system must be based on two principles: freedom and justice (Al-Qardhawi, 1997).

Freedom describes as freedom based on the values of monotheism and justice, not like the understanding of capitalists, which frees human actions to act and act without the intervention of any party. Thus, the balance between individuals with material and spiritual elements, the balance of individuals and society, and society with other communities is taken for granted.

The principle of justice in distribution is illustrated by the prohibition of assets that only circulate in certain groups, even though the wealth is expected to circulate comprehensively and contribute to the community's welfare (Qur'an of surah Al - Hasyr 7). Therefore, the accumulation of wealth by a group of people must be prohibited in the Islamic economic system. Islam suggests moving the flow of wealth to a lower class of society. In the interpretation of the Qur'an, a command that is highly recommended and must be applied in all aspects of life is an order to do justice. As explained in Surah of Qur'an Ar-Rahman (55) verses 7-9 towards justice in the economic field.

Therefore, the concept of distribution in Islamic Economics must be based on the basic principles of Islamic economics, namely individual freedom, social insurance, prohibition of accumulating wealth, and fair distribution of wealth.

c. Islamic Consumption

Consumption in Islamic economics has advantages for people, not the concept of utility, such as in capitalist economics. The achievement of advantages is the goal of maqasid syari'ah. The concept of utility is very subjective because it contradicts the fulfillment of satisfaction. The concept of advantage is relatively more objective as it is based on meeting needs. Advantages are fulfilled based on rational normative and positive considerations. Therefore, there are objective criteria in determining the advantages goods or no advantages goods. At the same time, the specified utility is more subjective because it will differ from one individual to another.

Islam teaches the follower to always carrying out everything that Allah has given in the Qur'an. Likewise in economic activities in the form of consumption activities encourage life to be frugal and not luxurious. This means that economic activities are intended only to fulfill the needs of life rather than the satisfaction of wants.

\section{CLOSING}

\section{Conclusion}

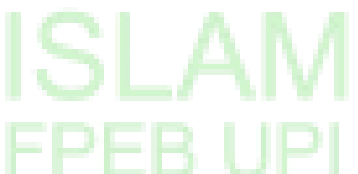

Production in the Islamic economy must be based on three fundamental aspects, namely aspects of belief, knowledge, and deed. Therefore, the benefit of individuals, families, communities, living things, and the earth could be achieved. On the other hand, the concept of distribution in Islamic economics must be based on the basic principles of Islamic economics, namely individual freedom, the existence of social insurance, prohibition of accumulating wealth, and fair distribution of wealth. Furthermore, the concept of consumption in Islam is intended to fulfill the needs of life rather than the satisfaction of wants.

\section{Suggestion}

The government must guarantee the fulfillment of social security, the prohibition of accumulating wealth, and the distribution of fair wealth. According to the Islamic economic concept, the community must generate a sense of obligation to carry out production, distribution, and consumption activities.

\section{REFERENCES}


Ahmad al-Haritsi, Jaribah bin. (2003). Fikih Ekonomi Umar bin Khatab. Jeddah: Dar al-Andalus.

Akmal Tarigan, Azhari. (2016). Praktek Monopoli dan Persaingan Usaha Tidak Sehat dalam Perspektif Hukum Ekonomi dan Hukum Islam. Mercatoria. Vol.9 (1).

Al-Qardhawi, Yusuf. (1997). Norma dan Etika Ekonomi Islam. Jakarta: Gema Insani Press.

Aslam Haneef, Mohamed. (2010). Pemikiran Ekonomi Islam Kontemporer terj.Suherman Rosyidi. Jakarta: Rajawali Pres.

Azhar Karim, Adiwarman. (2011). Ekonomi Mikro Islam, edisi ke-3. Jakarta: PT. Raja Grafindo Persada.

Ja'far A, Kumedi. (2012). Peranan Hukum Islam Dalam Pembangunan Ekonomi Di Indonesia. ASAS Jurnal Hukum Ekonomi Islam. Vol.4 (1).

Kunarjo. (2003). Glosarium Ekonomi, Kuangan dan Pembangunan Cet. Ke-1. Jakarta: Universitas Indonesia Perss.

Pujiono, Arif. (2006). Teori Konsumsi Islami. Jurnal Dinamika Pembangunan (JDP). Vol.3 (2).

Pusat pengkajian dan Pengembangan Ekonom Islam P3EI. (1998). Ekonomi Islam. Jakarta: PT. Raja Grafindo Persada.

Rahmawaty, Anita. (2013). Distribusi Dalam Ekonomi Islam Upaya Pemerataan Kesejahteraan Melalui Keadilan Distributif. EQUILIBRIUM. Vol.1 (1).

Rasyid, Suherman. (1998). Pengantar Teori Ekonomi Pendekatan Kepada Teori Ekonomi Mikro dan Makro. Jakarta: PT. Raja Grafindo.

Sari, Widya. (2014). Produksi, Distribusi dan Konsumsi Dalam Islam. Islamiconomic. Vol.5 (2).

Sudarsono, Heri. (2002). Konsep Ekonomi Islam, Suatu Pengantar. Yogyakarta: Ekonisia.

Sukarno, Fahrudin. (2010). Etika Produksi Perspektif Ekonomi Islam. Ekonomi Islam Al-Infaq. Vol.1 (1).

Turmudi, Muhammad. (2017). Produksi Dalam Perspektif Ekonomi Islam. Islamadina. Vol.XVIII (1).

Usman, Ermawati. (2007). Perilaku Produsen dalam Etika Bisnis Islam (Suatu Upaya Perlindungan Konsumen). Jurnal Hunafa. Vol.4 (3).

William D Nor Hans, Paul Samuel Son. (1993). Ekonomi, Jilid 1. Jakarta: Airlangga.

Yunia, Ika \& Kadir, Abdul. (2014). Prinsi Dasar Ekonomi Islam Perspektif Maqasid Al-Syari'ah. Jakarta: Prenadamedia Group. 